\title{
Swiss Multicenter Study Evaluating the Efficacy, Feasibility and Safety of Peginterferon-Alfa-2a and Ribavirin in Patients with Chronic Hepatitis C in Official Opiate Substitution Programs
}

\author{
Ronald Fried $^{\mathrm{a}} \quad$ Martine Monnat $^{\mathrm{b}} \quad$ André Seidenberg $^{\mathrm{c}}$ Robert Oppliger ${ }^{\mathrm{c}}$ \\ Patrick Schmid $^{d}$ Markus Herold $^{\mathrm{e}}$ Marc Isler $^{\mathrm{e}}$ Barbara Broers $^{\mathrm{f}}$ \\ Christoph Köllikerg ${ }^{\text {Peter Schönbucher }}{ }^{\mathrm{h}}$ Markus Frei $^{\mathrm{h}}$ Milo Huber $^{\mathrm{i}}$ \\ ${ }^{\mathrm{a}}$ Gastroenterology and Hepatology, Private Practice, Basel, ${ }^{\mathrm{b}}$ Centre Saint-Martin, Lausanne, \\ ${ }^{c}$ General Medicine, Private Practice, Zurich, d'Division of Infectious Diseases, Kantonsspital St. Gallen, \\ St. Gallen, ${ }^{e}$ ARUD (Arbeitsgemeinschaft für risikoarmen Umgang mit Drogen), Zurich, ${ }^{f}$ Division of Primary \\ Care Medicine, Department of Community Medicine and Primary Care, University Hospitals, Genève, \\ gBADAL (Basler Drogenabgabelokal der ARUD), Basel, h General Medicine, Private Practice, Luzern, and \\ 'Division of Infectious Diseases, University Hospital, Zurich, Switzerland
}

\section{Key Words}

Opiate substitution $\cdot$ Antiviral therapy $\cdot$ Hepatitis C

\begin{abstract}
Background: Though patients in opiate substitution programs are commonly infected with HCV, due to safety and efficacy concerns, they are rarely treated with interferon and ribavirin. Methods: In a multicenter study, HCV-infected patients in opiate maintenance treatment programs received $180 \mu \mathrm{g}$ pegylated interferon-alfa-2a once weekly, plus daily ribavirin for 24 weeks (genotypes 2, 3), or 48 weeks (genotypes 1, 4). Results: Of the 67 patients enrolled, 31 (46\%) had HCV genotypes 1 or 4, and 36 (54\%) had genotypes 2 or 3. Intent-to-treat analysis showed end-of-treatment virologic response in $75 \%$ of patients ( $81 \%$ of genotypes 2 or $3 ; 65 \%$ of genotypes 1 or 4), and a sustained virologic response in $61 \%$ of patients ( $72 \%$ of genotypes 2 or 3; $48 \%$ of genotypes 1 or 4). Fifteen patients (22\%) did not complete the study, in 5 (8\%) cases because of severe adverse events. Conclusions: Drug users with chronic HCV infection, regularly attending
\end{abstract}

an opiate maintenance program in which close collaboration between hepatologists/internists and addiction specialists is assured, can be treated effectively and safely with pegylated interferon-alfa-2a and ribavirin. Treatment results are very similar to those in other patient groups, and thus therapy should also be considered for this population.

Copyright $\odot 2008$ S. Karger AG, Basel

\section{Introduction}

Hepatitis C virus (HCV) infection causes chronic hepatitis in approximately $85 \%$ of those infected, and up to $20 \%$ of these develop liver cirrhosis as a late sequela [1]. Intravenous drug users (IDU) represent the core of the hepatitis $\mathrm{C}$ epidemic in the developed world. The literature cites infection percentages ranging from between 60 and even up to $100 \%$ of IDU being chronically infected, depending upon the individual's risk behavior and duration of intravenous drug use [2-8]. Viral transmission is still uncontrolled among IDU [8-12]. Seroprevalence in 
the general population ranges between 0.2 and $2 \%$. For Switzerland, estimates range from 0.5 to $1 \%$ of the population [13].

In many cases, depending on viral genotype, antiviral therapy of $\mathrm{HCV}$ infection with standard interferon-alfa (SIF) plus ribavirin (RBV) achieves sustained virologic response (SVR). The introduction of pegylated interferons (PEG-IFN) has further improved treatment responses [14-18].

The treatment of chronic hepatitis $\mathrm{C}$ in drug users remains controversial. Various national and international guidelines and consensus recommendations have excluded drug users from anti-HCV therapy $[19,20]$, whereas others have questioned this reasoning [3, 6, 21-23].

It was only in 2002 that the National Institute of Health consensus on medical management of HCV infection changed its recommendation to now consider treatment of IDU on a case-by-case basis [24]. Despite these newer recommendations, IDU still face many obstacles to HCV treatment, few have access to HCV treatment, and they are less frequently treated than other patient groups $[25$, 26].

The main reasons mentioned for excluding drug users from HCV treatment are the following:

- Presumed inadequate compliance;

- High rate of mainly psychological side effects;

- Risk of re-infection;

- Co-infection with hepatitis B or HIV;

- Treatment of HCV only after successful detoxification;

- Presence of contraindications for HCV treatment.

It has been shown $[22,23,25,27-30]$ that in the setting of opiate maintenance treatment (OMT; with methadone, heroin, buprenorphine or other opiates), HCV treatment with interferon (IFN) and ribavirin is feasible and safe, at least in small, highly selected groups of patients.

We conducted an open-label, phase IIIb multicenter study of HCV treatment with pegylated interferon-alfa2a plus ribavirin in drug users undergoing opiate maintenance treatment in Switzerland. The primary objective was to evaluate the efficacy of pegylated interferon-alfa$2 \mathrm{a}$ in combination with ribavirin in a relatively unselected group of chronic hepatitis $\mathrm{C}(\mathrm{CHC})$ patients participating in opiate substitution programs.

Secondary objectives were:

- To evaluate the efficacy of PEG-IFN plus RBV on the reduction of HCV viraemia after 4, 12, 24 and 48 weeks;
- To evaluate the efficacy of the combination therapy according to genotype and viral load of hepatitis C;

- To evaluate the efficacy of the combination therapy depending on patient's previous IFN treatment;

- To evaluate the safety of PEG-IFN plus RBV in patients with CHC participating in opiate substitution programs;

- To assess adherence to therapy during treatment with PEG-IFN plus RBV for patients participating in opiate substitution programs.

\section{Patients and Methods}

\section{Centers and Screening}

Eleven Swiss centers took part in the study. Most centers offer two forms of opiate substitution programs: oral substitution (methadone or buprenorphine) with a low threshold (evidence of dependence and two previous withdrawal attempts), and intravenous diacetylmorphine (heroin) substitution with high threshold criteria [31].

$\mathrm{HCV}$ antibody testing is offered, and in most cases performed, at the start of the opiate substitution treatment. Screening for participating in the HCV treatment study started only when adherence to maintenance treatment was achieved and chronic hepatitis was confirmed. During the screening phase, none of the patients had signs or symptoms suggesting acute HCV infection.

The patients provided their written informed consent to participate in the study, which had been previously approved by the local institutional review boards and conformed to the ethical guidelines of the 1975 Declaration of Helsinki.

\section{Patient Selection}

Men and women between 18 and 65 years of age, with serologically proven chronic hepatitis $\mathrm{C}$ and participating in an official opiate maintenance treatment program, but not previously treated with interferon-ribavirin combination therapy, were eligible for screening. During the screening phase, within 28 days prior to the first dose of pegylated interferon-alfa-2a and ribavirin, examinations established patient eligibility according to the inclusion/exclusion criteria.

Inclusion criteria were:

- Serum HCV PCR >600 IU/ml (COBAS Amplicor Monitor HCV RNS 2.0; Hoffmann-La Roche);

- Elevated serum ALT documented on at least one occasion within the past 6 months;

- Compensated liver disease (Child Pugh Grade A clinical classification in the case of cirrhosis);

- Ultrasound or MRI with no evidence of hepatocellular carcinoma;

- Serum AFP $<100 \mathrm{ng} / \mathrm{ml}$ and regular attendance at the treatment center.

A liver biopsy was not required on study entry, and other causes of liver disease were excluded by appropriate laboratory tests (anti-HAV IgM Ab, HBs-Ag, anti-HBc IgM-Ab; coeruloplasmin, ferritin, transferrin saturation; ANA, AMA). 
A noninvasive index, the AST to platelet ratio index (APRI), was calculated to estimate the percentage of patients with severe fibrosis or cirrhosis [32].

Patients were excluded from participation if they had:

- Neutropenia $\left(<1,500\right.$ neutrophils $\left./ \mathrm{mm}^{3}\right)$;

- Thrombocytopenia $\left(<90,000\right.$ platelets $\left./ \mathrm{mm}^{3}\right)$;

- Anaemia ( $<12 \mathrm{~g} \mathrm{Hg} / \mathrm{dl}$ in women and $<13 \mathrm{~g} \mathrm{Hg} / \mathrm{dl}$ in men);

- Human immunodeficiency virus (HIV) infection;

- Chronic hepatitis B;

- Decompensated liver disease;

- A serum creatinine level $>1.5$ times the upper limit of normal;

- Poorly controlled psychiatric disease;

- Substantial coexisting medical conditions;

- Were pregnant or breast feeding, or male partners of a pregnant woman.

Further exclusion criteria were:

- Therapy with any systemic antiviral, antineoplastic or immunomodulatory treatment within 6 months prior to the first dose of study drug, or with any investigational drug within 6 weeks prior to the first dose of study drug;

- Evidence of drug abuse including excessive alcohol consumption outside the official opiate substitution program;

- And inability or unwillingness to provide informed consent or abide by the requirements of this study.

\section{Treatment}

In this open-label, phase IIIb multicenter study, patients received once-weekly subcutaneous injections of $180 \mu \mathrm{g}$ pegylated interferon-alfa-2a, usually administered by a study nurse in the opiate maintenance treatment centers, plus daily ribavirin. In patients with genotype 2 or 3 , treatment was given for 24 weeks and the ribavirin dose was $800 \mathrm{mg} /$ day. In patients with genotype 1 and 4 , treatment was given for 48 weeks; the ribavirin dose was $1,000 \mathrm{mg} /$ day for patients weighing $<75 \mathrm{~kg}$, and $1,200 \mathrm{mg} /$ day for those weighing $>75 \mathrm{~kg}$. Clinical visits and laboratory investigations were performed at the screening visit 4 weeks before baseline, at baseline, and at weeks 1, 2, 4, 6, 8 and 12, and then every 6 weeks until 6 months after the end of treatment. Viremia was measured at weeks 4 and 12, at the end of treatment, and 6 months after the end of treatment.

Subsidiary endpoints were:

- Side effects, which were WHO graded;

- Dose reductions;

- Treatment interruptions;

- And dropouts.

Patients with no early virologic response at 12 weeks (RNA negativity or a drop in viral load by more than two logs) were given the option to discontinue treatment. In case of intolerance to study medication, doses were adjusted according to guidelines. HCV PCR was performed by local and approved laboratories using COBAS Amplicor Monitor HCV RNS 2.0 (Hoffmann-La Roche); HCV genotyping was performed with INNO Lipa HCV II (Bayer).

Most patients received all of their study medication at the same center where they received opiate substitution treatment. Those patients considered reliable enough to administer pegylated interferon-alfa-2a themselves were asked to return all used vials. All patients were asked to return open bottles, and tablet counts were made at each visit. Patients were considered compli- ant if they had taken at least $80 \%$ of the study medication for $80 \%$ of the planned treatment period.

Ribavirin was provided by Roche Pharma, Switzerland.

Statistics

The primary end-point of the study was a sustained virologic response to combined therapy, defined as a negative quantitative HCV-RNA determination 24 weeks after the end of treatment. All end-points were evaluated in an intent-to-treat analysis, including all patients who received at least one dose of study medication. Non-parametric tests were used for comparison of groups.

\section{Results}

\section{Patient Demographics}

Between March 2002 and June 2004, 67 patients from 11 treatment centers were enrolled in the study and received at least one dose of study medications. Of these, 49 were male, 18 were female; the mean age was 34 years. At baseline, 52 of 67 patients were receiving maintenance treatment with methadone alone, 7 used heroin and methadone, 3 only heroin, and 5 other opioids (buprenorphine or oral morphine). The mean duration of intravenous drug addiction was $156.7 \pm 59$ months. The estimated duration of $\mathrm{HCV}$ infection was $132.5 \pm 74.9$ months. Based on the APRI index (cut-off value $>1.5$ ), the estimated percentage of patients with severe fibrosis or cirrhosis was $25 \%$.

Further pretreatment characteristics of the patients are summarized in table 1 .

\section{Virologic Response}

In the intention-to-treat analysis, $75 \%$ of patients had nondetectable HCV RNA at the end of treatment (genotypes 2 and 3: 81\%; genotypes 1 and 4:65\%). Some $61 \%$ of patients (genotypes 2 and 3: 72\%; genotypes 1 and 4: 48\%) had a sustained virologic response 24 weeks after the end of treatment. Rapid virologic response at week 4 and early virologic response at week 12 are shown in figure 1. End of treatment response (75\%) was lower than early virologic response $(84 \%)$ because three patients experienced a breakthrough of HCV viremia during treatment and 2 patients dropped out during this phase of the study.

Patients who achieved SVR had been on opiate substitution for a shorter period (139.4 \pm 61 vs. $183.9 \pm 82$ months, $\mathrm{p}=0.0164$ ) than those with no SVR. This may reflect a shorter duration of $\mathrm{HCV}$ infection, which is one of the predictors of response. 


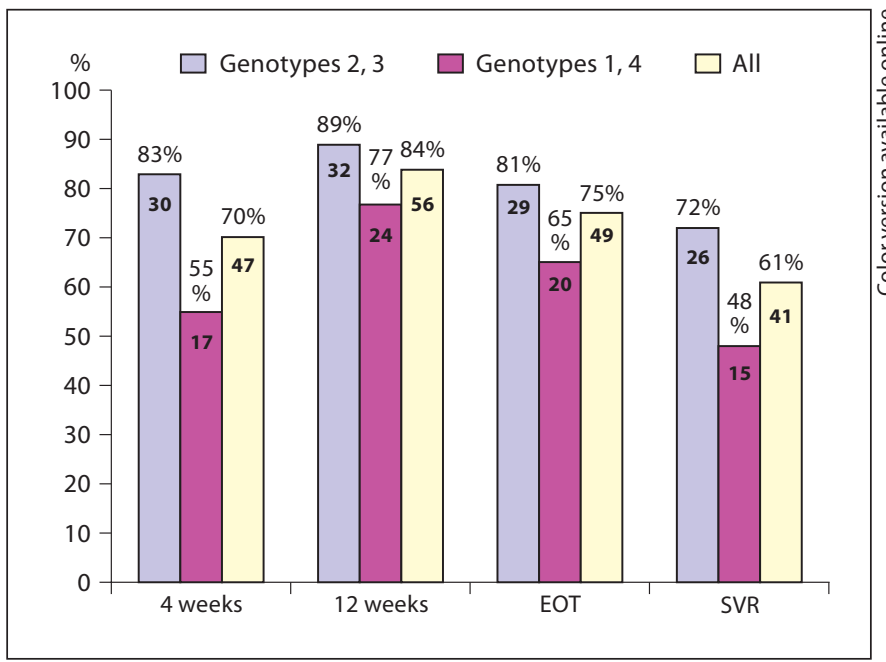

Fig. 1. Viral response rates. Virologic response at weeks 4 and 12 , end-of-treatment (EOT) virologic response and sustained virologic response (SVR), according to intention-to-treat analysis. A virologic response was defined as an undetectable level of $\mathrm{HCV}$ RNA $(<600 \mathrm{IU} / \mathrm{ml})$.

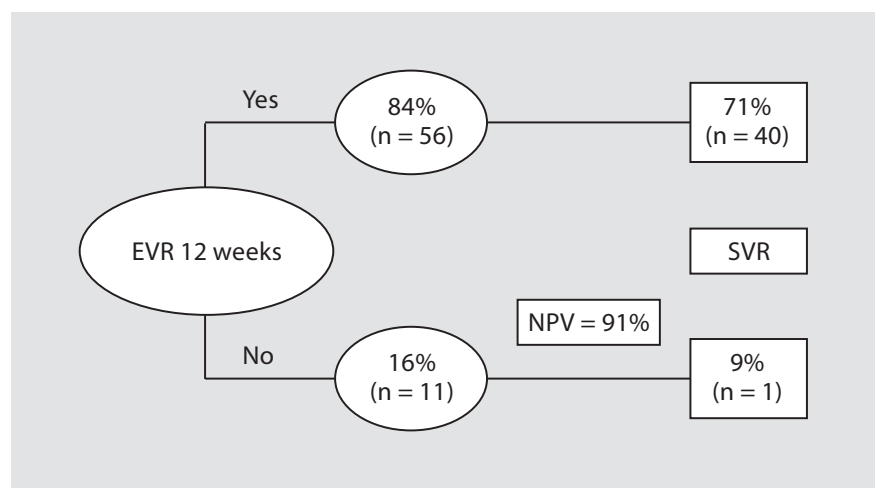

Fig. 2. Predictability of sustained virologic response. At week 12 , $84 \%$ (56 of 67 ) of the patients treated with peginterferon-alfa-2a plus ribavirin had an early virologic response (RNA negativity or a drop in viral load by more than two logs). Of these patients, $71 \%$ (40 of 56) went on to have a sustained virologic response (SVR). Of the 11 patients who did not have an early virologic response at week 12, 10 (91\%) did not have a sustained virologic response.

Patients with a pretreatment HCV RNA level of $\leq 500,000 \mathrm{IU} / \mathrm{ml}(\mathrm{n}=30$, SVR $77 \%)$ had a significantly better treatment response than those with a pretreatment HCV RNA level of $>500,000 \mathrm{IU} / \mathrm{ml}(\mathrm{n}=37$, SVR $49 \%$, $\mathrm{p}=0.02)$.
Table 1. Characteristics of patient population

$\begin{array}{lc}\text { Mean age, years (range) } & 34(21-56) \\ \text { Male/female, } \mathrm{n}(\%) & 49(73) / 18(27) \\ \text { Weight, kg } & 73.6 \pm 16.5 \\ \text { BMI } & 25.0 \pm 5.0 \\ \text { ALT, U/l } & 112 \pm 84 \\ \quad \text { Normal ALT } & 18 \% \\ \text { ALT 1-2 ULN } & 46 \% \\ \quad \text { ALT 2-3 ULN } & 13 \% \\ \text { ALT > ULN } & 22 \% \\ \text { Thrombocytes }<150,000 / \mu l & 12 \% \\ \text { APRI score [32] } & \\ \quad>1.5, \mathrm{n}(\%) & 17(25) \\ \quad>2.0, \mathrm{n}(\%) & 9(13) \\ \text { HCV RNA level, kIU/ml } & 2,571 \pm 5,021 \\ \quad \leq 500,000 \text { IU/ml } & 30(45 \%) \\ \text { >500,000 IU/ml } & 37(55 \%) \\ \text { HCV genotype, } \mathrm{n}(\%) & \\ \quad \text { Genotype 1 } & 25(37) \\ \text { Genotype 2 } & 2(3) \\ \text { Genotype 3 } & 34(51) \\ \text { Genotype 4 } & 6(9)\end{array}$

Of the 67 patients, four (three genotype 1, one genotype 2) had previously been treated unsuccessfully with interferon monotherapy. None of these patients achieved SVR.

\section{Predictive Value of Early Virologic Response}

By week 12, 84\% (56/67) of the patients treated with peginterferon-alfa-2a plus ribavirin showed an early virologic response, defined as no detectable serum HCV RNA or a drop in viral load by more than two logs (fig. 2). Of those with early virologic response, $71 \%$ subsequently had a sustained virologic response. In contrast, among the 11 patients who did not have an early virologic response, 10 (negative predictive value, NPV $=91 \%$ ) did not have a sustained virologic response.

\section{Safety}

From the 67 patients entering the study, $83 \%$ (6 discontinuations) with genotype 2 or 3 , and $69 \%$ (9 discontinuations) of those with genotype 1 or 4 , completed the study as planned. Premature study termination due to adverse events was observed in $5(8 \%)$ of the patients (table 2).

Dose modifications due to adverse events were frequently necessary (not all data shown). Only $37 \%$ of patients continued full treatment doses of pegylated interferon-alfa-2a and ribavirin. The need for ribavirin dose reduction was significantly more frequent in patients 
Table 2. Reasons for premature study withdrawal

\begin{tabular}{llll}
\hline & Genotype 2,3 & Genotype 1, 4 & All \\
\hline Adverse events & 2 & 3 & 5 \\
Lost to follow-up & 2 & 0 & 2 \\
Withdrawn consent & 2 & 1 & 3 \\
Other & 0 & 3 & 3 \\
NR after week 12 & - & 2 & 2 \\
\hline Total & 6 & 9 & 15
\end{tabular}

Table 3. Incidence of adverse events (occurring in more than $5 \%)$

\begin{tabular}{|c|c|}
\hline Blood system disorders overall $^{1}$ & $12(19 \%)$ \\
\hline Neutropenia/granulocytopenia & 6 \\
\hline Thrombocytopenia & 5 \\
\hline Anemia & 5 \\
\hline Eye disorders overall ${ }^{1}$ (various) & $6(9 \%)$ \\
\hline Gastrointestinal disorders overall ${ }^{1}$ & $28(42 \%)$ \\
\hline Nausea & 12 \\
\hline Vomiting & 8 \\
\hline Abdominal pain & 5 \\
\hline Upper abdominal pain & 5 \\
\hline Dyspepsia & 4 \\
\hline Nervous system disorders overall ${ }^{1}$ & $27(40 \%)$ \\
\hline Headache & 21 \\
\hline Psychiatric disorders ${ }^{1}$ & $31(46 \%)$ \\
\hline Depression & 20 \\
\hline Insomnia & 14 \\
\hline Thoracic disorders $^{1}$ & 9 \\
\hline Skin disorders overall ${ }^{1}$ & $28(42 \%)$ \\
\hline Alopecia & 10 \\
\hline Pruritus & 10 \\
\hline Dry skin & 5 \\
\hline General disorders ${ }^{1}$ & $42(63 \%)$ \\
\hline Fatigue & 29 \\
\hline Flu-like symptoms & 27 \\
\hline Irritability & 8 \\
\hline Injection site erythema & 5 \\
\hline Concomitant infections & 18 \\
\hline Anorexia & 9 \\
\hline Musculoskeletal pain & 9 \\
\hline
\end{tabular}

${ }^{1}$ Patients with at least one AE.

treated for 48 weeks (i.e. with genotypes 1 or 4 ) than in those treated for 24 weeks ( $69 \%$ vs. $40 \%, p=0.039$ ), whereas the need for dose reduction of pegylated interferonalfa-2a did not significantly differ between the groups (overall 55\%, $\mathrm{p}=0.09$ ). Though adverse events were seen in most patients, the most common reasons leading to dose reductions were granulocytopenia (6), thrombocytopenia (5), anemia (5), and a flu-like syndrome (2) (table 3).

Most adverse events were those commonly associated with interferon-based treatment (table 3). There were 188 events that occurred in the 36 patients treated for 24 weeks (genotypes 2 or 3 ), and 171 events were reported in the 31 patients treated for 48 weeks (genotypes 1 or 4 ). Severe adverse events (WHO grade 3 or 4 ) being reported more than once were neutropenia (3), thrombopenia (2), fatigue (3), anorexia (2), and headache (2). Psychiatric side effects grades 3 or 4 were rare. One severe episode of depression, one panic attack and one psychotic disorder were recorded. Rarely did serious adverse events lead to termination of the study (5 patients).

\section{Concomitant Medications}

Concomitant medications were prescribed for $77 \%$ of all patients at some point during the study. In particular, 10 patients (15\%) were taking antidepressants at entry and a further 15 patients (23\%) received antidepressants during the study for treatment of side effects. Two patients (3\%) took benzodiazepines at entry and a further 10 patients (15\%) received benzodiazepines during the course of the study.

\section{Discussion}

The treatment of HCV-infected patients who continue to take opiates, even in the setting of an opiate maintenance treatment program, is still a matter of debate. In this study, we report the results of treatment with pegylated interferon-alfa-2a plus ribavirin. As was observed in earlier studies, only a selected group of patients in opiate maintenance treatment were included. Among approximately 1,700 substituted patients at eleven Swiss treatment centers, 67 started treatment with pegylated interferon-alfa-2a plus ribavirin. Recruitment was slow and took longer than expected. The reasons for nontreatment were not assessed in the actual study, but were, in general, either patient- and/or physician-related. Nevertheless, in this setting, antiviral treatment with pegylated interferon-alfa-2a plus ribavirin proved feasible and safe. Efficacy, measured as SVR, was $61 \%$ across all virus genotypes. Compared to an overall sustained viral response of $47 \%$ in an earlier study with standard interferon and ribavirin in the same setting [30], the treatment response rate with pegylated interferon-alfa-2a was clear- 
ly higher, as has been shown in studies using the same therapies but requiring cessation of opiate use [18]. Patients with genotype 2 or 3 had a sustained virologic response rate of $72 \%$; those with genotype 1 or 4 had an SVR of $48 \%$. These response rates are very similar to those from previous studies requiring cessation of opiate use $[15,18]$.

A reappearance of $\mathrm{HCV}$ after early virologic response was observed in five patients. Most likely, this was due to a breakthrough and not to reinfection. No patient relapsed to i.v. drug use for the duration of the study. Even if individual patients had been injecting drugs during the course of the study, they most likely would have used clean needles and syringes, which are easily available in Switzerland.

Early prediction of virologic response to interferonbased therapy can help identify patients unlikely to have a sustained response, and allow clinicians the option to discontinue treatment, thereby saving patients side effects and cost of additional therapy. There is now a consensus that treatment should be discontinued in patients who do not achieve early virologic response by week 12 [33]. The current study suggests that this also holds true for opiate substituted patients: $91 \%$ of our patients who did not have an early virologic response by week 12 did not achieve a sustained virologic response. These results are very similar to those in larger studies involving nonIDU patients.

One of the reasons for the reluctance of hepatologists to treat IDU with HCV infection is a supposed noncompliance and a higher rate of dropouts from treatment programs. In a previous treatment study with pegylated interferon-alfa-2b plus ribavirin in patients on methadone maintenance, sustained virologic response was $42 \%$ in the methadone group, and thus lower, though not statistically significantly so, than the $56 \%$ in the control group $(\mathrm{p}=0.16)$. The main reason for this difference appeared to be a higher rate of early treatment discontinuation within the first 8 weeks due to non-compliance or patient request [34]. In a recent paper, Guadagnino et al. [35] showed that patients treated in a multidisciplinary management model had treatment responses not different from those achieved in non-IDU patients. Other, retrospective studies found similar compliance rates and responses to therapy among IDU and non-IDU patients [36]. Treatment compliance rates for IDU in other chronic diseases, such as tuberculosis or HIV [37], are similar to cohorts of non-IDU, and healthcare providers cannot reliably predict patients who are likely to be compliant with the prescribed regimen. Previous studies have indi- cated that active IDU with CHC infection can achieve an SVR, particularly if they comply with at least two-thirds of their scheduled clinic visits, and are attending a multidisciplinary clinic that includes both hepatologists/internists and specialists in addiction medicine [27-29]. In our study, patients were treated at the same center where they also received opiate maintenance treatment, further assuring compliance with scheduled visits.

Side effects of treatment were common in this study; however, serious side effects leading to premature withdrawal occurred in less than $10 \%$ of patients (5 of 67). The side effects did not differ in character or frequency from those of earlier published studies with treatment using pegylated interferon and ribavirin. Serious psychiatric side effects were very rare. This may be due to the fact that patients received antidepressants and/or benzodiazepines as deemed necessary by the treating physician. Overall, at some point during the study, $38 \%$ of patients were prescribed antidepressants and $18 \%$ benzodiazepines.

Some limitations apply to the results of this study. Although our findings are encouraging, the number of treated patients was small and we did not include a control group of non-IDU patients. We also did not assess why more patients in opiate maintenance treatment programs did not receive HCV treatment. Clearly, there is a selection bias, although the same can be said for treatment studies in non-IDU patients [38]. In a previous screening study among Swiss patients on opiate maintenance treatment, the type and distribution of reasons for nonparticipation of hepatitis $\mathrm{C}$ seropositive candidates were assessed using a semistructured questionnaire [39]. In less than half of all candidates, a decision for or against treatment was actually made. The rest had either a negative hepatitis $\mathrm{C}$ serology, or other reasons were given for nonparticipation. Some $80 \%$ of the reasons for nonparticipation in the treatment study were based on protocol issues. The three most frequent were normal liver values, co-infection with HIV, and negative HCV RNA. These together accounted for nearly half of all protocol-based refusals.

In our earlier study [30], only $6 \%$ of all infected patients were eligible for treatment; indeed, a recently published study cited an even lower percentage [6]. Our study is therefore not able to answer the important question of whether treating a larger proportion of $\mathrm{HCV}$ infected IDU and using less stringent selection criteria would still be effective and safe. Also, we cannot answer the question as to which elements of addiction treatment programs, which patient characteristics, or what type of collabora- 
tion model between hepatologists and physicians prescribing opiates are critical for success. In this context, we should not forget that in Switzerland and several other countries, many patients receive their opiate maintenance treatment through primary care physicians, and that thoughts about collaboration models should include these groups. As do others, we believe that the need for such research is urgent in the view of the high prevalence of $\mathrm{HCV}$ infection among this population.

In summary, our results indicate that HCV therapy of patients treated in opiate treatment programs with pegylated interferon-alfa-2a plus ribavirin is feasible, safe and efficacious, with SVR rates similar to those from previous studies in non-IDU patients. Close collaboration between hepatologists/internists and specialists in the treatment of addiction seems to be important, and patients should preferably be treated in a setting where they also receive opiate maintenance treatment. Further community-based studies are required to better define the natural history of the disease, and to determine the safest and most effective treatment regimen for this group of patients. Better strategies should be developed to include more IDU patients in HCV treatment programs. Enhanced collaboration between hepatologists and specialists in treatment of addiction should be encouraged. For that purpose, the allocation of more resources in terms of funding and manpower is an imperative and would allow treatment of larger numbers of IDU patients. Indeed, IDU patients now constitute a large part of the HCV-infected population in most countries of the developed world.

\section{Acknowledgments}

The authors wish to thank Roche Pharma, Switzerland, for supporting this project and Kathleen Bucher for editorial assistance.

\section{References}

1 Marcellin P, Asselah T, Boyer N: Fibrosis and disease progression in hepatitis C. Hepatology 2002;36(5 suppl 1):S47-S56.

-2 Broers B, Junet C, Bourquin M, Deglon JJ, Perrin L, Hirschel B: Prevalence and incidence rate of HIV, hepatitis B and C among drug users on methadone maintenance treatment in Geneva between 1988 and 1995. AIDS 1998;12:2059-2066.

-3 Edlin BR: Prevention and treatment of hepatitis $\mathrm{C}$ in injection drug users. Hepatology 2002;36(5 suppl 1):S210-S219.

-4 Steffen T, Gutzwiller F: Hepatitis B and C in intravenous drug abusers in Switzerland. Schweiz Rundsch Med Prax 1999;88:19371944.

5 Bruggmann P, Seidenberg A, Meili D, Kesseli B, Huber M: Hepatitis-C- und HIVPrävalenz sowie antiretrovirale Therapie in einem niederschwelligen Opiatsubstitutionsprogramm - Eine Querschnittsanalyse. Suchttherapie 2005;6:78-82.

-6 Hagan H, Latka MH, Campbell JV, Golub ET, Garfein RS, Thomas DA, Kapadia F, Strathdee SA; Study to Reduce Intravenous Exposures Project Team: Eligibility for treatment of hepatitis $C$ virus infection among young injection drug users in 3 US cities. Clin Infect Dis 2006;42:669-672.

7 Roy K, Hay G, Andragetti R, Taylor A, Goldberg D, Wiessing L: Monitoring hepatitis C virus infection among injecting drug users in the European Union: a review of the literature. Epidemiol Infect 2002;129:577585.
8 Edlin BR, Carden MR: Injection drug users: the overlooked core of the hepatitis C epidemic. Clin Infect Dis 2006;42:673-676.

-9 Garfein RS, Doherty MC, Monterroso ER, Thomas DL, Nelson KE, Vlahov D: Prevalence and incidence of hepatitis $\mathrm{C}$ virus infection among young adult injection drug users. J Acquir Immune Defic Syndr Hum Retrovirol 1998;18(suppl 1):S11-S19.

10 Hagan H, Thiede H, Weiss NS, Hopkins SG Duchin JS, Alexander ER: Sharing of drug preparation equipment as a risk factor for hepatitis C. Am J Publ Health 2001;91:4246.

11 Hahn JA, Page-Shafer K, Lum PJ, Bourgois P, Stein E, Evans JL, Busch MP, Tobler LH, Phelps B, Moss AR: Hepatitis C virus seroconversion among young injection drug users: relationships and risks. J Infect Dis 2002; 186:1558-1564.

12 Judd A, Hickman M, Jones S, McDonald T, Parry JV, Stimson GV, Hall AJ: Incidence of hepatitis $\mathrm{C}$ virus and HIV among new injecting drug users in London: prospective cohort study. BMJ 2005;330:24-25.

13 Grob PJ, Negro F, Renner EL: Hepatitis CVirus-Infektion. Praxis 2000;89:1587-1604.

14 Zeuzem S, Feinman SV, Rasenack J, Heathcote EJ, Lai MY, Gane E, O’Grady J, Reichen J, Diago M, Lin A, Hoffman J, Brunda MJ: Peginterferon alfa-2a in patients with chronic hepatitis C. N Engl J Med 2000;343:16661672 .
15 Manns MP, McHutchison JG, Gordon SC, Rustgi VK, Shiffman M, Reindollar R, Goodman ZD, Koury K, Ling M, Albrecht JK: Peginterferon alfa-2b plus ribavirin compared with interferon alfa- $2 \mathrm{~b}$ plus ribavirin for initial treatment of chronic hepatitis C: a randomised trial. Lancet 2001;358:958-965.

16 Lauer GM, Walker BD: Hepatitis C virus infection. N Engl J Med 2001;345:41-52.

17 Chander G, Sulkowski MS, Jenckes MW, Torbenson MS, Herlong HF, Bass EB, Gebo KA: Treatment of chronic hepatitis C: a systematic review. Hepatology 2002;36(5 suppl 1):S135-S144

18 Fried MW, Shiffman ML, Reddy KR, Smith C, Marinos G, Goncales FL Jr, Häussinger D, Diago M, Carosi G, Dhumeaux D, Craxi A, Lin A, Hoffman J, Yu J: Peginterferon alfa-2a plus ribavirin for chronic hepatitis $C$ virus infection. N Engl J Med 2002;347:975-982.

19 EASL International Consensus Conference on Hepatitis C. Paris, 26-27 February 1999. Consensus statement. J Hepatol 1999;31(suppl 1):3-8.

20 Keeffe EB, Hollinger FB: Therapy of hepatitis C: consensus interferon trials. Consensus Interferon Study Group. Hepatology 1997; 26(3 suppl 1):101S-107S.

21 Davis GL: Treatment of chronic hepatitis C. BMJ 2001;323:1141-1142.

22 Edlin BR, Seal KH, Lorvick J, Kral AH, Ciccarone DH, Moore LD, Lo B: Is it justifiable to withhold treatment for hepatitis $\mathrm{C}$ from illicit-drug users? N Engl J Med 2001;345: 211-215. 
-23 Backmund M, Meyer K, Von Zielonka M, Eichenlaub D: Treatment of hepatitis C infection in injection drug users. Hepatology 2001;34:188-193.

24 National Institutes of Health Consensus Development Conference: Management of Hepatitis C: 2002. Hepatology 2002;36(5 suppl 1):S3-S20.

25 Schaefer M, Heinz A, Backmund M: Treatment of chronic hepatitis $\mathrm{C}$ in patients with drug dependence: time to change the rules? Addiction 2004;99:1167-1175.

-26 Broers B, Helbling B, François A, Schmid P, Chuard C, Hadengue A, Negro F; Swiss Association for the Study of the Liver (SASL 18): Barriers to interferon-alpha therapy are higher in intravenous drug users than in other patients with acute hepatitis C. J Hepatol 2005;42:323-328.

-27 Backmund M, Reimer J, Meyer K, Gerlach JT, Zachoval R: Hepatitis C virus infection and injection drug users: prevention, risk factors, and treatment. Clin Infect Dis 2005; 40(suppl 5):S330-S335.

$>28$ Sylvestre DL: Treating hepatitis C in methadone maintenance patients: an interim analysis. Drug Alcohol Depend 2002;67:117123.
29 Sylvestre DL, Litwin AH, Clements BJ, Gourevitch MN: The impact of barriers to hepatitis $\mathrm{C}$ virus treatment in recovering heroin users maintained on methadone. J Subst Abuse Treat 2005;29:159-165.

30 Huber M, Weber R, Oppliger R, Vernazza P, Schmid P, Schönbucher P, Bertisch B, Meili $\mathrm{D}$, Renner EL: Interferon alpha-2a plus ribavirin 1,000/1,200 $\mathrm{mg}$ versus interferon alpha-2a plus ribavirin $600 \mathrm{mg}$ for chronic hepatitis $\mathrm{C}$ infection in patients on opiate maintenance treatment: an open-label randomized multicenter trial. Infection 2005; 33:25-29.

31 Rehm J, Gschwend P, Steffen T, Gutzwiller F, Dobler-Mikola A, Uchtenhagen A: Feasibility, safety, and efficacy of injectable heroin prescription for refractory opioid addicts: a follow-up study. Lancet 2001;358:14171423.

32 Wai CT, Greenson JK, Fontana RJ, Kalbfleisch JD, Marrero JA, Conjeevaram HS, Lok AS: A simple non-invasive index can predict both significant fibrosis and cirrhosis in patients with chronic hepatitis C. Hepatology 2003;38:518-526.

33 Davis GL: Monitoring of viral levels during therapy of hepatitis C. Hepatology 2002;36: S145-S151

-34 Mauss S, Berger F, Goelz J, Jacob B, Schmutz G: A prospective controlled study of interferon-based therapy of chronic hepatitis $\mathrm{C}$ in patients on methadone maintenance. Hepatology 2004;40:120-124.
35 Guadagnino V, Trotta MP, Montesano F, Babudieri S, Caroleo B, Armignacco O, Carioti J, Maio G, Monarca R, Antinori A; Nocchiero Study Group: Effectiveness of a multidisciplinary standardized management model in the treatment of chronic hepatitis $\mathrm{C}$ in drug addicts engaged in detoxification programmes. Addiction 2007;102:423-431.

36 Robaeys G, Van Vlierberghe H, Mathei C, Van Ranst M, Bruckers L, Buntinx F: Similar compliance and effect of treatment in chronic hepatitis $\mathrm{C}$ resulting from intravenous drug use in comparison with other infection causes. Eur J Gastroenterol Hepatol 2006;18: 159-166.

37 Broers B, Morabia A, Hirschel B: A cohort study of drug users' compliance with zidovudine treatment. Arch Intern Med 1994;154: 1121-1127.

38 Shehab TM, Orrego M, Chunduri R, Lok AS: Identification and management of hepatitis $\mathrm{C}$ patients in primary care clinics. Am J Gastroenterol 2003;98:639-644.

39 Huber M, Schmid P, Vernazza P, Meili D: Gründe für die ausbleibende Hepatitis C Behandlung bei Drogenabhängigen in Opiatsubstitution. Suchtther Suppl 2002;3:S27S30. 